\title{
Study on the Efficacy of Biological Agents on Black Pepper (Piper nigrum L.) against Root Knot Nematode, Meloidogyne incognita
}

\author{
T. Senthilkumar ${ }^{1 *}$ and M. Ananthan ${ }^{2}$ \\ ${ }^{1}$ Department of Plant Protection, Anbil Dharmalingam Agricultural College and Research \\ Institute, Tiruchirappalli-620009, India \\ ${ }^{2}$ Horticultural Research Station, Thadiyankudisai, Dindigul- 624 212, Tamil Nadu, India \\ *Corresponding author
}

\section{A B S T R A C T}

A nursery experiment was conducted to evaluate the efficacy of different biological agents such as Pseudomonas fluorescens (Pfbv 22), Bacillus subtilis (Bbv 57), Trichoderma

\section{Keywords}

Black pepper,

Biological agents,

Root knot

nematode, Nursery

\section{Article Info}

Accepted:

26 June 2018

Available Online:

10 July 2018 viridi, Biodynamic compost and AM fungi on root knot nematode management in black pepper. The study indicated that all the biological agents were found to have potential to increase significant plant growth in terms of number of leaves and plant biomass. The maximum number of leaf per plant was recorded in $P$. fluorescens ( $\mathrm{Pfbv} 22$ ) treated plants (40 per cent) significantly different from untreated control followed by B. subtilis (Bbv 57), Biodynamic compost, AM fungi as 25 per cent. Among the treatments $T$. viridi and carbofuran registered the minimum number of leaf 3 . The maximum plant biomass of 50 per cent was recorded in P. fluorescens ( $\mathrm{Pfbv} 22$ ) and it was on par with Biodynamic compost and AM fungi. The next best treatment was B. subtilis (Bbv 57) (37.5 per cent) and it was also on par with AM fungi treatment. The $M$. incognita alone recorded least bio mass of $20 \mathrm{~g}$. The population of root knot nematode $M$. incognita in soil and roots were significantly lower in all biological agents treated cuttings than untreated control. The percent reduction in nematode population in soil, egg mass $/ \mathrm{g}$ and adult female nematode/g was maximum in $P$. fluorescens with $60.1,41.2$ and 38.1 percent respectively over untreated control.

\section{Introduction}

Black pepper Piper nigrum L., known as 'King of Spices' is the most important and most widely used spice in the world. In Tamil Nadu, black pepper growing areas are Lower Pulney's, Servaraayan and Kolli hills. The production share of Tamil Nadu is $851 \mathrm{MT}$ from 3,745 ha (NMCE, 2006). In India, generally yield varies widely in different areas and depends on several factors such as pest and diseases, soil fertility, climate, age of vine, etc. The low productivity and crop loss due to pests and diseases has been identified as a major constraint in the production of black pepper. The major disease identified in black pepper are 'slow wilt' caused by root knot nematode Meloidogyne incognita prevailing in lower pulney hills of Tamil Nadu. Slow wilt is the most harmful disease, 
which spreads rapidly destroying a large number of vines, estimated at about 20 per cent of the total crop almost every year. Several factors were responsible to spread of plant parasitic nematodes from one place to another place. Among this infestation and spread of nematodes through rooted cutting is foremost important one. Hence, an attempt was made to select efficient biological agent for the management of root knot nematode a nursery experiment was conducted in the existing popular black pepper variety 'Panniyur 1'.

\section{Materials and Methods}

A nursery experiment in completely randomized block design was conducted at Horticultural Research Station, Thadiyankudisai with seven treatment and three replication to evaluate efficacy of different biological agents such as $P$. fluorescens, B. subtilis, T. viridi, Biodynamic compost and AM fungi on root knot nematode management in black pepper. The talk formulation of PGPR consortium is the combination of two bacterial strain $P$. fluorescens (Pfbv 22) and B. subtilis (Bbv57) developed by Jonathan et al., (2006) Department of Nematology, Directorate of Plant Protection Studies, Tamil Nadu Agricultural University, Coimbatore and commercially available $T$. viridi, biodynamic compost, AM fungi were used in this experiment. The nursery mixture was prepared and filled with polythene bags. Good and disease free black pepper cuttings was selected and planted in the polybags containing nursery mixture. Before planting the poly bags containing nursery mixture were incorporated with $P$. fluorescens (5g/cutting), B. subtilis (5g/cutting), T. viridi ( $5 \mathrm{~g} /$ cutting), Biodynamic compost (5g/cutting), AM fungi (5g/cutting), carbofuran $3 \mathrm{G}$ (10g/cuttings) along with untreated control for check. All the poly bags were inoculated with second stage juveniles of root knot nematode $M$. incognita
@ one juvenile/g of soil. The trial was concluded 120 days after nematode inoculation. At the time of termination of the experiment observation such as soil nematode population $(250 \mathrm{~g})$, female population in root $(1 \mathrm{~g})$, number of egg mass in $1 \mathrm{~g}$ of root and gall index of root knot nematode $M$. incognita were recorded. The plant growth characters of number of leaf per plant and plant biomass also recorded. Statistical analysis were done and tabulated.

\section{Results and Discussion}

The results of the study indicated that all the biological agents such as $P$. fluorescens ( $\mathrm{Pfbv}$ 22), B. subtilis (Bbv57), T viridi, Biodynamic compost and AM fungi were found to increase the plant growth in terms of number of leaves and plant biomass, but varied significantly in improving the biomass between the treatments. The maximum number of leaf per plant was recorded in $P$. fluorescens (Pfbv 22) treated plants (40 per cent) significantly different from untreated control followed by $B$. subtilis (Bbv57), Biodynamic compost, AM fungi recorded as 25 per cent. Among the treatments T. viridi and carbofuran recorded the minimum number of leaf (3). The maximum plant biomass of 50 per cent was recorded in $P$. fluorescens (Pfbv 22) and it was on par with Biodynamic compost and AM fungi. The next best treatment was B. subtilis (Bbv57) (37.5 per cent) and it was also on par with AM fungi treatment. The $M$. incognita alone treated pepper plants found to record least bio mass of $20 \mathrm{~g}$. The population of root knot nematode $M$. incognita in soil and roots were significantly lower in all biological agents treated cuttings than untreated control. The final soil nematode population, number of egg mass/g of root and number of adult female/g of root was also reduced by the application of all the biological agents. The percent reduction in nematode population in soil, egg mass/g and adult female nematode/g was maximum in $P$. fluorescens with $60.1,41.2$ and 38.1 percent respectively over untreated control (Table 1). 
Table.1 Management of root knot nematode Meloidogyne incognita in black pepper through biological agents

\begin{tabular}{|c|c|c|c|c|c|c|}
\hline Treatments & $\begin{array}{l}\text { Nematode } \\
\text { population } \\
(250 \mathrm{~g} \text { soil) }\end{array}$ & $\begin{array}{c}\text { No. of } \\
\text { female } \\
/ \mathrm{g} \text { of } \\
\text { root }\end{array}$ & $\begin{array}{l}\text { No. of egg } \\
\text { mass/g of } \\
\text { root }\end{array}$ & $\begin{array}{l}\text { Gall } \\
\text { Index }\end{array}$ & $\begin{array}{l}\text { Number of } \\
\text { leaves } \\
\text { /Plant }\end{array}$ & $\begin{array}{l}\text { Seedling } \\
\text { weight }\end{array}$ \\
\hline $\begin{array}{l}\text { T1-Pseudomonas fluorescens Pfbv } 22 \text { (5 g per } \\
\text { cutting) }\end{array}$ & 135 & 13 & 10 & 2 & 5 & 50 \\
\hline T2-Bacillus subtilis Bbv 57 (5 g per cutting) & 153 & 15 & 13 & 3 & 4 & 41 \\
\hline T3-Trichoderma viride (4 g per cutting) & 154 & 17 & 13 & 3 & 3 & 38 \\
\hline T4-Biodynamic compost ( 5 g per cutting) & 137 & 12 & 12 & 2 & 4 & 48 \\
\hline T5-VAM Fungi (5 g per cutting) & 141 & 13 & 11 & 2 & 4 & 47 \\
\hline T6-carbofuran 3G (10g/cutting) & 125 & 8 & 9 & 1 & 3 & 33 \\
\hline T7-Untreated control & 338 & 21 & 17 & 4 & 3 & 30 \\
\hline CD (0.05) & 12.2061 & 1.7514 & 1.4802 & & 1.7514 & 5.7328 \\
\hline
\end{tabular}


The present study was designed to determine bio-control potential of $P$. fluorescens (Pfbv 22) and B. subtilis (Bbv57) along with other bio-control agents. In general all the biocontrol agents were capable of reducing the root knot nematode population. The plant growth promotion may be related to the suppression of nematode population in rhizosphere (Burr et al., 1978). The plant growth promoting rhizobacteria may promote growth by secreting plant hormones (Lifshits et al., 1987). The $P$. fluorescens and $P$. aeruginosa producing gibberellic acid (Katznelson and Cole, 1965) and the production of Indole Acetic Acid by $P$. fluorescens (dubeikovsky et al., 1993) was responsible for plant growth. Soil application of $P$. fluorescens recorded maximum yield with consequent management of nematode fungal disease complex in grapevine reported by Senthilkumar and Rajendran (2003). Similarly Rajeswari SundaraBabu et al. (1996) observed that AM fungi as biofertilizer applied at the ragi, the plants were able to grow well with ill effect caused by the nematode, Rotylenchulus reniformis and gave higher yield. Hence it was concluded that application of $P$. fluorescens (Pfbv 22) may be a promising practice in management of root knot nematode in pepper.

\section{References}

Burr, T.J., M.N. Schroth and T. Suslow. 1978. Increased potato yield by treatment of seed pieces with specific strains of Pseudomonas fluorescens and Pseudomonas putida. Phytopathology, 8: 1377-1387.
Dubeikovsky, A.N., E.A. Mordukhova, V.V. Polikarpora and A.M. Boronin. 1993. Growth promotion of black current soft wood cuttings by recombinant strain Pseudomonas fluorescens BSP 53a synthesizing an increased amount of indole - 3 - acetic acid. Soil Biology and Biochemistry, 25: 1277 - 1281.

Jonathan, E.I., A. Sandeep, I. Cannayane and R. Umamaheswari. 2006. Bioefficacy of Pseudomonas fluorescens on Meloidogyne incognita in banana. Nematologia Meditteranea, 34: 19-25.

Katznelson, $\mathrm{H}$ and S.E. Cole. 1965. Production of gibberellin substances by bacteria and actinomycetes. Canadian Journal Microbiology, 11: 733-741.

Lifshits, R., J.W. Kloepper, M. Kozlwski, C. Simonson, J. Cavison, E.M. Tipping and I. Zaleska. 1987. Growth promotion of canola (rapeseed) seedling by a strain of Pseudomonas putida under gnotobiotic conditions. Canadian Journal of Microbiology, 33: 390-395.

Rajeswari Sundar Babu, C. Sankaranarayanan and G. Jothi. 1996. Interaction of VAM and biofertilizers on the nematodes associated with ragi. International Journal of Tropical Plant Diseases. 11:85-87.

Senthilkumar, T. and G. Rajendran. 2003. Studies on wilt disease expression in the presence of Meloidogyne incognita and Fusarium moniliforme in grapevine. Nematologia meditteranea, 31: 187-189.

\section{How to cite this article:}

Senthilkumar, T. and Ananthan, M. 2018. Study on the Efficacy of Biological Agents on Black Pepper (Piper nigrum L.) against Root Knot Nematode, Meloidogyne incognita. Int.J.Curr.Microbiol.App.Sci. 7(07): 3693-3696. doi: https://doi.org/10.20546/ijcmas.2018.707.426 